\title{
Research on Malicious Green Barriers in International Trade
}

\author{
Xiaoxia $\mathrm{Yu}^{1}$ \\ ${ }^{1}$ Weihai Vocational College, Weihai, $\quad$ Shandong Province, 264210, China
}

Keywords: Malicious green barriers; Forms; Impact; Countermeasures

\begin{abstract}
Each country has different representative position. In order to protect their own interests, many countries with scientific and technological advantages formulate malicious green barriers through legislations and strict mandatory laws with an excuse of protecting human health and protecting environment. They set restrictions on imports from other countries and adopt double standards in international trade. Based on the author's experience, this paper analyzes the main forms of malicious green barriers and discusses the impact of malicious green barriers. Finally, this paper proposes countermeasures.
\end{abstract}

\section{Introduction}

Green barriers refers to direct, indirect or even forbidden laws, regulations, policies and measures in trade to protect life, health and safety of human, animals and plants and protect the ecology or environment. The definition of this concept is essentially based on the following two points: first, the external manifestation of green barriers is regulations, policies and measures taken by states; the second is the nature of green barriers, namely technical barriers to trade to protect the environment or the health of human being, animals and plants, which is a kind of non-tariff barriers. If the importing country adopts trade protection with a so-called environmental protection and its real aim is to use its technological advantages to prevent products from developing countries entering its market, this can be called malicious green barriers, which should be boycotted and prevented in international trade.

\section{Main Forms of Malicious Green Barriers}

To implement discriminatory standard in the same product from specific countries. If the importing country implements discriminatory environmental protection standard for products or specific products in a specific country, which is different from other countries, this discriminatory environmental protection standard will have a lot of subjective malice. Its real intention may use strict high standards to prevent country-specific products from entering its domestic market and its essence is trade protectionism. This is clearly contrary to the non-discrimination principle in WTO most favored nation clause. Japan implements double standards in export products from China. They have a sampling inspection of $10 \%$ imports of processed eel goods from China, while only $5 \%$ of those from other countries. Moreover, Japan's new policy has also cast doubt on some kind of malice. Since Japan's eel import is mainly from China, Japan often only take strict measures on China's eel goods. However, there are no more rules for other fish. This behavior has obvious pertinence, which is not allowed by the principle of WTO.

To implement double environmental protection standards in domestic and imported products. If the importing country implements two different standards for the domestic and imported products, 
which is double standards and which treats domestic and imported products without the same and non-discriminatory standards, the essence of this double standard is to prevent foreign products to enter the domestic market. This is obviously contrary to the non-discriminatory principle of national treatment. Japan had double standards in residual quantity of low-toxic chlorpyrifos. The residual quantity of imported spinach does not exceed $0.01 \mu \mathrm{g} / \mathrm{g}$, while the domestic spinach has limited to $3 \mu \mathrm{g} / \mathrm{g}$. The following are some regulations: rape $2 \mu \mathrm{g} / \mathrm{g}$, Chinese cabbage and cabbage $1 \mu \mathrm{g} / \mathrm{g}$, tomato $0.5 \mu \mathrm{g} / \mathrm{g}$. All these provisions make discrimination of green barriers exposed.

To extend the scope, increase items and improve the rigor in product test and inspection. Developed countries use its complex green technology standards and advanced technology to increase items, extend the scope and improve the rigor in product test and inspection. Exports from developing countries are often subject to a number of technical indexes to attend to one thing and lose another. For example, China's exports of agricultural products only have 6-7 detected pesticides before entering WTO. Now test projects are as many as 134 kinds. The pesticide residues inspection is also from the previous six to 62 kinds in relevant provisions of tea imports in the EU market.

\section{The Impact of Malicious Green Barriers}

Tedious Standards increase the trade cost, which is not conducive to the development of international trade. In recent years, developed countries often implement unilateral trade measures with an excuse of protecting the environment to restrict imports of foreign products, which leads to many bilateral or multilateral trade conflicts. Developed countries often have advanced technologies and are in technical monopoly position. By means of legislations and strict mandatory technical environmental standards, developed countries limit imports of foreign goods. These standards are established in accordance with the level of production and technology, which can be achieved by developed countries. However, it is difficult to achieve for our country. Our country is a developing country and a energy superpower, but China's exports of many products cannot reach the White Swan System of four Nordic countries, the EU system of European Union, Environmental Choice System of Canada, Eco-labeling system of Japan and a series of regional standards in many countries due to technology and poor awareness of environmental protection. Therefore, the amount of foreign trade is relatively lower in many areas in our country.

Green barriers easily lead to trade disputes and retaliation. Due to the different purpose of implementation of green barriers and different understanding of international standards, as well as gains and losses involved in interests in economic trade, trade disputes are inevitable which are triggered by green barriers and even form intense trade conflicts. When a country suffers losses caused by malicious green barriers, the country is bound to retaliate on trading partners in the same way, which not only affects the normal development of international trade, but also affects bilateral relations or even the multilateral relations between the two countries.

Polluting industries are transferred to developing countries. On environmental issues, developed countries take a two-way standard. On one hand, they set green barriers to prevent products with unmatched standard from entering their markets. On the one hand, they encourage domestic enterprises with serious pollution and damage to transfer into developing countries. As developing countries have few relative environmental protection laws and regulations and low environmental standards, this makes it possible for developed countries to transfer a number of high-pollution, high-consumption and even toxic waste and polluting products into developing countries. 
To develop green ecological industry. We should establish green trade system, promote green production, promote green lifestyle and link the green trade, green economy and green lifestyle into the whole process of China's economic and social development. China should learn from the successful experience of foreign companies which break through the green trade barriers and we should be in accordance with international practice to promote the ISO14000 environmental management system certification and issue a green flag to enterprises which pass the certification. On the basis of the implementation of environmental certification system, we must establish and improve our own environmental standards and technical regulations, and actively participate in mutual recognition of international standards. We should sign multilateral or bilateral recognition agreements in order to eliminate trade friction from the perspective of system. Rationally deal with the dual effect of standardization work environment and upgrade our own environmental standards. Moreover, we should promote the rational use of resources, reduce product costs and improve international competitiveness.

To upgrade the industrial structure and improve product quality. In recent years, overproduction caused by similar technology, product homogeneity and the market concentration of exports, leads to vicious competition in the domestic, foreign green barriers or even a chain round of the block. The key measure to response to green barriers scientifically and expand exports, is to upgrade the industrial structure and improve product quality from the perspective of sustainable development. We should pay attention to encourage and guide enterprises to take advantage of marketing channels in general trade export and a mature manufacturing method, which means to take the development road of featured trade processing. Moreover, we should vigorously promote the upgrading of processing trade, focus on optimizing the export structure, strengthen technical innovation, support for exports of goods with independent brands and independent intellectual property rights and improve the export price and added value. Support deep-processing and precision-machined agricultural exports. The introduction of advanced and applicable technologies and comprehensively enhancing of independent innovation capability are important to promote comparative advantage from low-end technology to high-end technology.

To strengthen cooperation of international legislation. We should make full use of preferential treatment for developing countries in Technical Barriers to Trade and the mechanism for trade dispute settlement of WTO to protect fair trade opportunities for Chinese enterprises. To provide preferential treatment for developing countries is a fundamental principle of WTO on goods trade between the developed and developing member countries. As the member states formulate and implement national technical standards, regulations and verification procedures, they should give full consideration to the special needs of developing countries in trade and provide appropriate exceptions to ensure that its technical standards, regulations and verification procedures do not create unnecessary obstacles to exports of developing countries. However, developing countries need to get a really hard fight to gain these treatments. Therefore, China should put forward preferential treatments and argue on the basis of reasons with its trade partner country. We should make a reasonable use of mechanism for trade dispute settlement of WTO to protect the interests of foreign trade and fair trade business opportunities in China.

To strengthen the research on international product quality standards. In order to meet the needs of agricultural internationalism, we should make a research on the international standards of Codex Alimentarius Commission, International Bureau of Veterinary Medicine and the International Botanical Gardens Conservation. At the same time, Chinese enterprises should improve management and strengthen international certification. ISO14000 is formulated by the International Organization for Standardization (ISO) to promote sustainable development, coordinate 
management standards in all countries and reduce non-tariff barriers in world trade. The standard is to improve environmental management by establishing a scientific and standardized environmental management system within the enterprise and links environmental protection and market directly. It does not limit the absolute amount, but concern about whether it is compliant with environmental regulations and whether it is consistent with commitment. Therefore, it is a shortcut to get rid of green barriers.

To gradually establish an early warning mechanism to green barriers. Establish an early warning mechanism to deal with green barriers as soon as possible. We should regularly collect, collate, publish the latest changes in foreign green barriers and pay close attention to changes in agricultural laws, regulations, standards and price of international organizations, importing countries and international market. This may encourage Chinese enterprises to improve the product at an early stage to improve product quality, so that the green barrier is useless.

To give full play of industry associations and governments in trade disputes. When agricultural products face malicious green barriers, relying on individual is not suitable for the economic interests of the individual and the collective interest of the industry development. On the contrary, the coordination and negotiation of trade associations between nations can minimize costs and reduce political factors in trade friction. Meanwhile, industry associations can help enterprises and relevant government departments to communicate effectively and strengthen negotiation finality of relevant government departments to reduce search costs for related information. Foreign trade associations play important role in the agricultural products circulation and our associations are still in its infancy, but the association plays an increasingly important role in future trade negotiations.

\section{Conclusion}

A good ecology is the highest productivity. At present, whether the production process and products are injected into green factors has become a proof whether products can add value. Therefore, we must adopt overall environmental protection strategy in the production process, establish ecological concepts of environmental protection and economic development and take the road of sustainable development. Moreover, we should take green reformation in production, marketing, packaging and other aspects and integrate the consumer demand, business interests and environmental protection to improve the environmental competitiveness of products and develop the international market for green products. Furthermore, we should guide various types of enterprises to take environmental protection as their main value, establish sustainable development of export commodity structure and establish a good cycling economic structure to comprehensively normalize and promote the development of China's foreign trade.

\section{References}

[1] Wu Cuixia. A Discussion of Malicious Green Barriers in International Trade [J]. Commercial Times, 2006, 13: 34-35.

[2] Cai Jiachen. The Characteristics and Countermeasures of Malicious Green Barriers [J]. Modern Business, 2010, 09: 143-144.

[3] Cui Ge. The Determination and Countermeasures of Malicious Green Barriers [J]. Journal of Henan Institute of Science and Technology, 2010,03: 13-16.

[4] Dong Chunli. The Influence and Countermeasures of Malicious Green Barriers for China [J]. Modern Economic Information, 2008, 09: 122-123. 
[5] Zhang Yimin. A Discussion of Malicious Green Barriers in International Trade [J]. Consume Guide, 2007, 11: 65. 